\title{
Regional Tourism Development Planning: A Structured Literature Review
}

\author{
Zainul Rahman* \& Salahudin \\ Government Science Study Program, Faculty of Social and Political Sciences, \\ University of Muhammadiyah Malang, Indonesia
}

Received: 10 May 2021; Review: 28 June 2021; Approved: 14 July 2021

\begin{abstract}
This study aims at categorizing the themes and concepts that become problems in the study of regional tourism development. Various issues regarding related articles in several countries were then collaborated and used as references for developing regional tourism in Indonesia in the future. This study was a structured literature review with the main data source obtained through the SCOPUS database. The SCOPUS database was considered very relevant and comprehensive to be used to prepare discussions on related themes. This study revealed several aspects that influenced regional tourism development in several countries to be a reference to be applied in Indonesia. The parts are: First, a well-integrated collaboration. Second, strong political will from the government. Third, the presence or active participation of the local community. Fourth, carried out planning in a systematic and integrated manner. Finally, the fifth is the subject involved as policymakers. The limitations of this study were the lack of comprehensive comparisons reviewed in each cluster. It was based on the rules of the data found by the authors, especially those that were only contained in the SCOPUS database. Through these existing limitations, it is expected that further study can enrich references from other databases for the study's progress. Thus the discussion of related themes can be a detailed study and very useful in influencing regional tourism development policies in Indonesia in the future.

Keywords: Development Planning; Regional Tourism Development.
\end{abstract}

How to Cite: Rahman, Z. \& Salahudin, S. (2021). Regional Tourism Development Planning: A Structured Literature Review. JPPUMA: Jurnal Ilmu Pemerintahan dan Sosial Politik UMA (Journal of Governance and Political Social UMA), 9 (2): 150-162

${ }^{*}$ Corresponding author:

ISSN 2549-1660 (Print)

E-mail: zainulrahman720@gmail.com

ISSN 2550-1305 (Online) 


\section{INTRODUCTION}

The development of tourism in an area is an important thing to strive for. Regional tourism development basically must begin with careful planning (Ponte et al., 2020). Planning is an important aspect that needs to be considered to avoid failure or less than optimal efforts to develop regional tourism. Otherwise, planning is a fundamental aspect since there have been so many efforts made by both the government and stakeholders related to regional tourism development that is less than optimal and even fails (Lopes et al., 2020). To develop regional tourism, welldesigned planning will impact regional progress; it will certainly grow the community's economy and increase the selling value of an area, especially in the tourism sector (Kalves et al., 2020).

Development planning is a benchmark designed to facilitate realizing a development goal (Wikantiyoso et al., 2021). Development planning must strive for involving relevant stakeholders; in development planning at the local level, planning must involve the top-level government (central) as well as local government and related parties in the region (NGOs) (Wang, 2020). It is aimed that the development policies can run in harmony with what they should be. If there is no unified communication at the central and local government levels, it will certainly impact development planning and implementation failures. Otherwise, if the central and local governments can establish good communication and coordination, it will certainly support achieving the vision of the development planning itself.

Regional tourism development cannot be separated from the support of business people, NGOs, political parties, NGOs, and various other stakeholders. The private sector also has a fundamental role in supporting the progress of regional tourism. Cooperation between the government, the private sector, and the community is the main key to the success of regional tourism development. The built collaboration will encourage regional tourism development success; it is because the various stakeholders are experts in their respective fields (Luhtala et al., 2021). Apart from cooperation, good promotion is needed to attract local and foreign tourists in developing regional tourism. Publication and advertising are important aspects of the tourism business.

Regional tourism development is one of the priority programs of the Indonesian government. However, efforts to develop regional tourism in Indonesia were still not optimal due to various obstacles. Regional tourism development that aims to increase local revenue and grow local communities' economies has not been implemented comprehensively. Multiple challenges to the growth of regional tourism in Indonesia include planning errors, human resources, political will from the central and provincial governments, etc. (Pebriana et al., 2021). Through this structured literature review, the author describes how the pattern of regional tourism development is carried out by most other countries to be considered and applied in Indonesia.

A review paper or a review of previous studies is a basis taken by the author in compiling this study. Review papers are important to find out and examine how issues related to related themes have been previously researched and can be used as references to be developed in Indonesia. Various great writers in multiple countries also study a lot of associated articles. The diversity of viewpoints, issues discussed, study locations, and research methods enrich the author's understanding in compiling this study. The review paper method is important because the steps taken by the author can find out the discussions of previous research. The author can find a wide variety of discussions related to related themes. Through this paper review method, the author must be more careful in sorting the pieces following the study of regional tourism development. In addition, the authors can also understand and learn from some of the shortcomings or limitations that exist in previous studies. It is the author's capital to review regional tourism development to produce maximum and relevant conclusions.

The difference between the discussions in previous studies and this study is that some previous studies have examined regional tourism development planning by scanning the object of study in a narrow sense or on a single issue. In contrast, this study analyzed and collaborated on various kinds of regional tourism development problems related to 
regional tourism development in multiple parts of the world to be a reference for regional tourism development in Indonesia. Multiple kinds of limitations in the development of regional tourism found by the authors in previous studies are an important value that can consider for the development of regional tourism in Indonesia in the future. The authors took a systematic and structured literature review step. The main data source was the literature review sourced from the SCOPUS database. The data were processed using VosViewer to produce relevant conclusions. Previous studies have examined problems related to regional tourism development from various aspects. Therefore, this study collaborated between multiple factors that existed previously. It did not only touch on the theoretical level but also practices specific to regional tourism development in Indonesia. This study discussed the various backgrounds of the countries studied with varied scopes of study. This study can provide a conceptual picture in overcoming the problems of regional tourism development in Indonesia. In other words, Indonesia, a country with a diverse composition of regional tourism, can give birth to ways of approaching and handling regional tourism development problems that are different from other countries. Otherwise, through this literature review, it is expected to provide additional references regarding the issues of regional tourism development to resolve them properly through regulations and models that are unique or appropriate to be applied in Indonesia.

\section{RESEARCH METHOD}

researched to analyze various articles that correlate with tourism development issues at the regional/local level. Multiple articles published in international journals were the data sources used in this study. The reviews in this study were based on several questions, including 1) How does the government design regional tourism development plans? 2) What were the relevant and dominant themes in the discussion related to regional tourism development? 3) What topics were correlated with regional tourism development? 4) What were the concepts used in the study related to regional tourism development? 5) What type of mapping was used in the study of regional tourism development?

Various questions, as described previously, became the basic reference used by the authors in reviewing the fundamental theme carried out. Obtained Sources of articles through the SCOPUS database. Reviewed The articles found were based on two stages, including 1) Searching for articles and 2) Mapping of discussion topics.

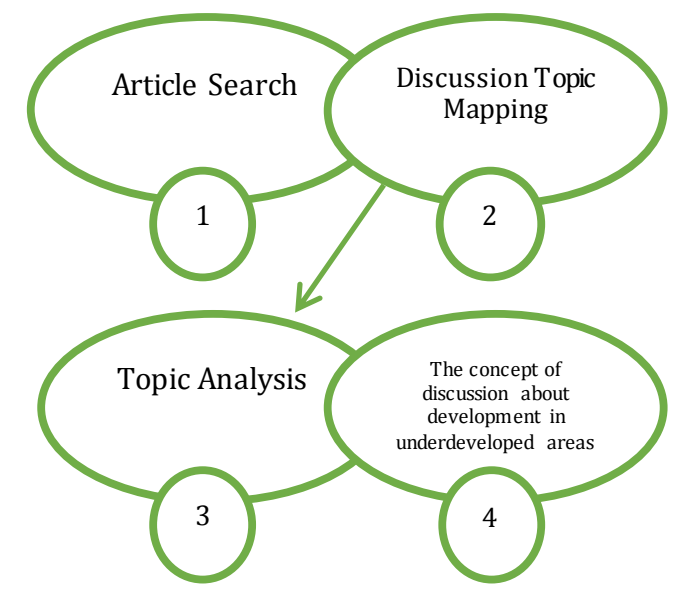

Table 1. (article review process)

The authors obtained various related articles in the following ways: First, identify the pieces. Identifying themes can be intended to sort multiple articles so that only those aligned with the topic discussed. Did it by entering the keywords "Regional Tourism Development Planning" in the search column with restrictions from 2020 to 2021. Through this search, the authors obtained several 1,593 articles relevant to the topics discussed. The second stage is to verify the various articles found to focus on the pieces needed to compile related studies. The verification carried out resulted in 129 articles/journals assessed based on the research topic. After narrowing as many as 129 articles, 52 articles/journals were found, mapped based on their respective clusters, and judged to be appropriate and relevant to the authors' main topic.

\section{RESULTS AND DISCUSSION}

\section{Correlation and Grouping of Themes} Related to Regional Tourism Development Planning

This description continued the verification process obtained through various journals that have been previously selected. Furthermore, the review results, which were processed using the VOSViewer application, mapped concepts based on 
groups. Figure 1 shows the various concept names derived from the cluster density view. A color distinction is an indication of differentiation between one group and another. It aims to make it easier to identify existing themes. It also makes it easier for researchers to proceed to the next stage of research. Figure 1 shows the different colors in each existing cluster.

As vosviewer

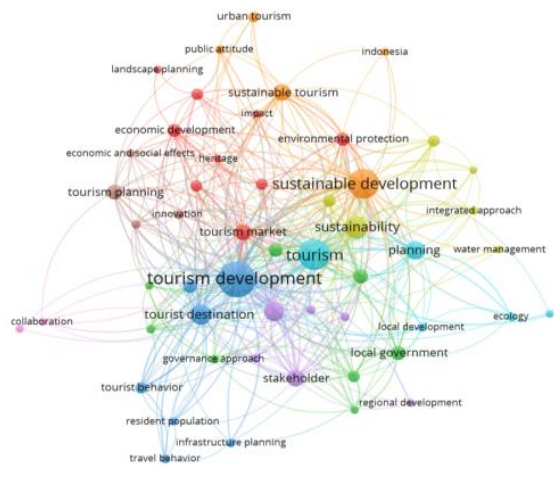

Figure 1. (Theme Relationship in Regional Tourism Development Studies)

The identification results, as shown in Figure 1, are very helpful for researchers in the process of studying the themes discussed. This method was optimal since it allowed the researchers to find many existing articles that correlate with the themes discussed. The following table lists the existing clusters:

Table 2. (Themes divided by bunch)

In cluster 1, the dominant theme was tourism development)". The study explained discussed by Syapsan \& Diartho (2020); the that innovation in tourism development is very study examined "Natural tourism area significant. Tourism is inseparable from the development (Study on Jember district economic aspect, simply due to good

\begin{tabular}{|c|c|c|}
\hline Group & Concept Name & Total \\
\hline $\begin{array}{c}\text { Cluster } \\
1\end{array}$ & $\begin{array}{l}\text { Community development, cultural tourism, economic development, environmental } \\
\text { protection, impact, tourism market. }\end{array}$ & 9 \\
\hline $\begin{array}{c}\text { Cluster } \\
2\end{array}$ & $\begin{array}{l}\text { Decision making, governance approach, institutional framework, local government, } \\
\text { planning process, rural development, tourism economy. }\end{array}$ & 8 \\
\hline $\begin{array}{c}\text { Cluster } \\
3\end{array}$ & $\begin{array}{l}\text { Infrastructure planning, local participation, population, tourism development, } \\
\text { behavior development, sustainability. }\end{array}$ & 7 \\
\hline $\begin{array}{c}\text { Cluster } \\
4\end{array}$ & $\begin{array}{l}\text { Development, integrated approach, local community, } \\
\text { sustainability, water management. }\end{array}$ & 6 \\
\hline $\begin{array}{c}\text { Cluster } \\
5\end{array}$ & $\begin{array}{l}\text { Policymaking, regional development, stakeholders, sustainable tourism development, } \\
\text { tourism management }\end{array}$ & 6 \\
\hline $\begin{array}{c}\text { Cluster } \\
6\end{array}$ & Architectural heritage, ecology, regional development, planning, tourism. & 5 \\
\hline $\begin{array}{c}\text { Cluster } \\
7\end{array}$ & $\begin{array}{l}\text { Indonesia, public attitudes, sustainable development, sustainable tourism, urban } \\
\text { tourism. }\end{array}$ & 5 \\
\hline $\begin{array}{c}\text { Cluster } \\
8\end{array}$ & Economic and social efforts, innovation, strategic planning, tourism planning & 4 \\
\hline $\begin{array}{c}\text { Cluster } \\
9\end{array}$ & Community collaboration and participation. & 2 \\
\hline
\end{tabular}


innovation in tourism development has an impact on economic growth. Another discussion that also has causality with cluster 1 is as discussed by Kalvet et al. (2020). His writing found that tourism development also required collaboration from various related parties. The article entitled "Innovative tools for tourism and cultural tourism impact assessment" also emphasized the importance of using innovative tools and data in tourism management.

In the context of Indonesia, regional tourism development often clashed with relevant stakeholders, even though the key to tourism development in the region, if it underlined the study, required integrated collaboration between relevant stakeholders. Good communication and cooperation could produce perfect policies and bring innovations in managing regional tourism in Indonesia.

Cluster 2 discusses massively related to local government efforts in tourism development planning. Almeida \& Silveira (2021), in their article entitled "Collaborative Tourism Planning in Small Municipalities. The Creation of a Local Development Strategy for Pombal (Portugal) Through the Application of the Delphi Technique," found that the role of local governments was very fundamental in increasing regional tourism. The study, conducted in Pombal, Portugal, found that the provincial government carried out no strategic intervention in tourism development planning, which led to the non-optimal development of tourism potential in the area that was the center of the study. Otherwise, the government in regional tourism development efforts must make extra efforts; these extra efforts could be carried out with active initiatives from local governments to collaborate with local communities to create good synergy in efforts to develop regional tourism (Brillo, 2020).

Political will from the local government was the main aspect in efforts to develop regional tourism. Strong intervention from local governments was able to support success in regional tourism development. In Indonesia, the provincial government's efforts in developing regional tourism tend to depend on the central government. It was undeniable considering the dependence of the allocation of funds from the APBDN. To support this success, local governments must be massive and innovative in creating successful tourism development in their area.

Cluster 3 discusses the participation of residents in regional tourism development. Hui et al. (2020) explained that the involvement of local communities living in areas close to tourism development was very important for developing the tourism sector. However, this study found a problem that emphasized the lack of local community participation in ecotourism development in National Parks in Malaysia. The article entitled "Local community participation in ecotourism at National Park in Pahang, Malaysia" identified that socio-economic factors have a strong tendency in the level of participation of local communities. To invite strong involvement of local/village governments and local communities, it was necessary to understand the cultural and customary values that existed in an area.

The participation of local communities needs to be considered in the study of regional tourism development. Nguyen et al. (2020) examined a collaboration between policymakers and local communities in Vietnam. The study results stated that the community in determining policies was not to be taken into account. Various approaches were considered one-sided or top-down systems. In this case, the community was the Kinh Tribe, felt unable to participate actively in the policy formulation or planning process. These things need to be avoided, considering that the local community was a person who was quite familiar with the area and the potential that existed to be developed. If you put this aside, it was the same as triggering failure in regional tourism development.

The active participation of residents is one of the supporting factors in efforts to develop regional tourism. In Indonesia, regional tourism development plans were rooted in and dominated by the government as policymakers, even though the orientation of regional tourism development was one of them to raise the economic level of local communities. (Anandhyta \& Kinseng, 2020). Local communities should be more active in contributing to tourism development in their area and not only rely on the government or the private sector itself. It can certainly increase the effectiveness of regional tourism development. 
Cluster 4 focuses on integrated or sustainable efforts in regional tourism development. Candia et al. (2020) explained that sustainable tourism could make a significant contribution to the economic development of local communities without causing negative impacts on the physical, social and cultural environment of a tourist destination. Through an approach taken with strategic steps, it certainly supported the growth of regional tourism. It can also state that to develop regional tourism; it was necessary to plan policies that were integrated or in line with the vision of the economy, environmental sustainability, culture, and so on that exist in an area.

Cluster 5 discusses the subject or those involved as policymakers. Wang's (2020) article, which discussed "Institutional interaction and decision making in China's rural development," described that the institutional interaction between two formal institutions (central and village governments) in China in making village tourism development decisions was the key to tourism growth. Their interactions explained the final decision and implementation related to rural development and provided examples of rural governance. Although it had commonly applied institutional theory in Western countries and cases, its application in China was rare. This study considered the suitability of this theory to explore rural governance in China based on the subject of rural tourism development.

Policymakers in efforts to develop regional tourism are one of the main aspects. Policymakers must be able to innovate in planning regional tourism development. Innovation and creativity possessed by officeholders have a great influence; the government's courage as policymakers in making breakthroughs that can change the situation of an area was very key. Therefore the importance of innovation from the policymakers themselves in efforts to develop regional tourism (Casanova Enault et al., 2021).

The study in cluster 5 emphasized that subjects involved in regional tourism development (central and provincial governments) must first have a harmonious vision. In Indonesia, it is still often found that there are contradictions in the desire or direction of regional tourism development between the central and local governments. It should be avoided to bring success in the development of regional tourism in Indonesia.

Cluster 6 discusses the reciprocity or ecology of governance, both between living things and nature. Hengky \& Kikvidze (2020), in their article entitled "Sustainable Coastal Tourism in Tanjung Kelayang, Indonesia," explained that there are three important components in tourism management. The three main components are: (1) the effectiveness of coastal tourism management planning policies, (2) increasing socioeconomic activities, and (3) minimizing environmental impacts. The third point, which relates to environmental impacts, is an important aspect of regional tourism management. It was to prevent the impact of environmental damage caused by efforts or development in tourism development.

Otherwise, the Philippines is one of the countries that is aggressively developing ecotourism. Ecotourism is a key strategy in promoting local development in the Philippines. But even though, the country has some limitations in the development of ecotourism. It is due to there being still many tourism resources in rural areas that have not been utilized and developed. The less optimal role of the government was a supporting aspect of the inhibition of ecotourism development in the Philippines. In addition, the government has not been able to escape the discussion of the impacts faced by efforts to develop ecotourism, especially the effects on the environment (Brillo, 2020).

In Indonesia, regional tourism development also has many impacts on the destruction of its natural resources. The bad effect on the ecosystem was caused by the lack of good planning from the local government before implementing tourism development policies in the area. It should be avoided by careful planning through various considerations, especially from the environmental aspect(Prathama et al., 2020).

Cluster 7 emphasizes sustainable tourism. Saneinia et al. (2020) attempted to examine related issues in their review entitled "A holistic view of tourism development and potential policy concerns: A case of Birjand City, Iran". This study sought to explore the influence of culture in Birjand City by using the SWOT method to find solutions for tourism 
development in this city. The implications highlight future challenges that policymakers, legislators, and academics could potentially face when discussing tourism as a competence, industry, and game-changing player in the country's economic growth. The policies suggested by this article can help achieve sustainable development in South Khorasan Province and Birjand City. This survey attempted to assess the impact of globalization on local sustainability and regional stability. In essence, it is important to examine the longterm effects of sustainable tourism planning; it was done to prevent the negative impacts of mistakes in tourism development.

Next, can understand that sustainable tourism planning is a strategy that the government must carry out. Sustainable tourism is one of the keys to success in regional tourism development. Sustainable tourism can be interpreted as a proactive effort made by the government to create growth and progress in regional tourism development. There must be sustainability in every policy program; tourism innovation must also be made, not static (Tanaka et al., 2021).

Cluster 8 focuses on tourism strategy and innovation. Ratnasari et al. (2020), in their article entitled "An experience of tourism development: How is the strategy?" explained that tourism was one of the sectors that were sufficient to determine the economic welfare of the local community. To create sustainable integration, tourism development needs to pay attention to aspects of facilities, tourists, and the surrounding community. The object of this study was to contribute to the development of tourism in Samarinda City with a strategy that involves organizational innovation, knowledge management, organizational learning, and transformation of leadership in the tourism community (government, business actors, and society). Innovation in tourism development determined the output of the strategy or efforts undertaken,

Tourism is one of the sectors that can determine the economic welfare of the local community. To create sustainable integration, tourism development needs to pay attention to aspects of facilities, tourists, and the surrounding community. To realize this sustainable integration, a good tourism strategy and innovation are required. Local governments must be able to innovate and create various reforms in the tourism sector. Something unique and new in the world of tourism certainly attracts many tourists. This is what answers why tourism innovations and strategies are so important to be initiated (Ratnasari et al., 2020)

Various kinds of strategies and innovations in developing regional tourism in Indonesia have to be further expanded. Designs and innovations must be oriented towards attractive renewal so that tourism development in the region can be more optimal. Reflecting on the efforts to develop tourism in other countries such as those previously reviewed, Indonesia must at least innovate with a renewal strategy if it wants to attract tourists, both local and foreign.

Finally, cluster 9 discusses collaboration and massive community participation. Community collaboration and participation are critical to securing sustainable tourism and highlight the need to listen to and respond to various stakeholder voices, opinions, and concerns. These concepts dominate the discourse of sustainable, responsible tourism and give rise to the theory of collaboration and multiple types of community participation (Eyisi et al., 2020). The article entitled "Facilitating collaboration and community participation in tourism development: The case of South-Eastern Nigeria" concluded that to develop tourism destinations that were friendly to residents and maintain collaboration and community participation, stakeholders needed education about tourism and opportunities to participate in planning. The involvement of these stakeholders is the key to the success of regional tourism development.

In addition, a collaboration between the government and local communities, and other stakeholders was considered capable of minimizing disputes between related parties. In this case, it can state that collaboration can minimize social jealousy between associated parties. Harmonizations in cooperation were the key to unity. Union also needed to be carried out considering that regional tourism development efforts must maximize various related aspects to realize the vision proclaimed when policy planning was initiated (Caamañofranco \& Suárez, 2020). 
Otherwise, Nel \& Connelly (2020) reveal that in the absence of a governance process that allowed collaborative planning to resolve conflicts over future trajectories for an area, disputes over land use, resources, and access were likely to continue. Supporting the previous review, this article considered collaboration very important since it could help the vision of successful regional tourism development. Various kinds of cooperation were the key to unifying goals; it would be difficult to develop tourism in an area when the plans were scattered. That is why this collaboration is an important part to do, whether initiated by the government, private parties, and local communities, to maximize regional tourism development in Indonesia.

\section{Dominant Theme in the Study of Regional Tourism Development}

There are several dominant themes or those that are closely related to the themes discussed. It is necessary to classify dominant themes or categories so that the study is more focused and systematic. Organizing dominant themes will greatly assist the author in mapping out any discussion that has a strong relationship with the topic being observed. Reviewing regional tourism development studies, absolutely must sort out and choose any theme or category in harmony so that it does not deviate far from the topic being reviewed. The following are some of the dominant themes found in the study of regional tourism development:

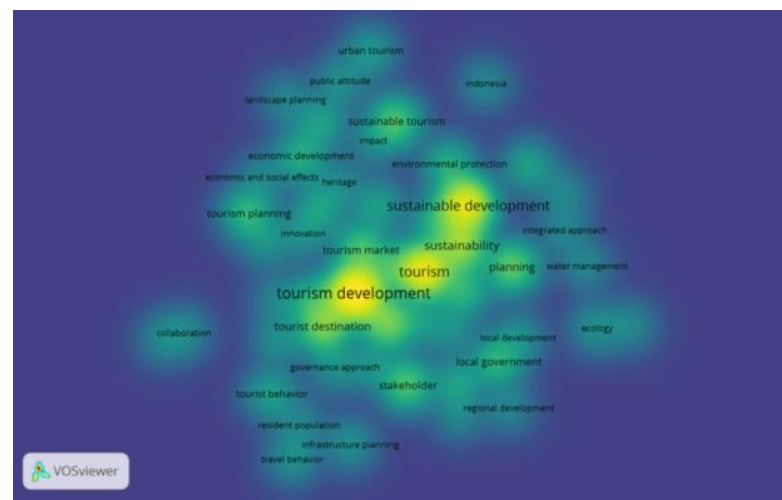

Figure 2. (Dominant concept related to regional tourism development studies)

Searching for the previous discussion topics, especially about regional tourism development, one can find some of the most dominant words. The classification to see took the dominant theme was taken through the VOSViewer application. The prevalent words or themes include Tourism development, tourism, sustainability, sustainable development, planning, sustainable tourism, tourism destinations, stakeholders, collaboration, ecology, innovation, regional development, impact, economic planning, population, infrastructure planning, Indonesia, heritage, and travel behavior.

These various kinds of words have differences in terms of color thickness, which shows that words with colors that tend to be bold have a dominant relationship with the themes discussed by several previous studies. The various kinds of prevalent words have complex causality or interrelationships, making it easier for the author to draw conclusions related to the theme discussed, namely regional tourism development planning.

Based on the dominant concept related to the study of regional tourism development, as seen in Figure 2, several words dominate (shown by the thickness of the color). The first is sustainable; in this case, regional tourism development must be sustainable, cannot be done simply, and must go through several stages, from planning to the final step. The second is development planning; in essence, one must study based on a mature and comprehensive plan to develop regional tourism. The third is tourism development; the important aspect is the tourism potential itself. The last is stakeholders. The role of stakeholders is one of the most influential aspects of regional tourism development efforts. In this case, stakeholders include the government (central and regional), local communities, business people, and so on. Good collaboration and cooperation between relevant stakeholders will greatly influence efforts to develop potential in an area. Some of the important points in these dominant themes were aspects that need to be considered and used as references in planning regional tourism development in Indonesia.

\section{Dominant Author in Regional Tourism Development Studies}

Several previous authors have previously discussed studies related to regional tourism development studies. Although the focus of the study discussed is 
not monolithic, at least several authors studied and examined the discussion associated with the related theme. The following are some of the author's names that discuss related to previous regional tourism development studies:

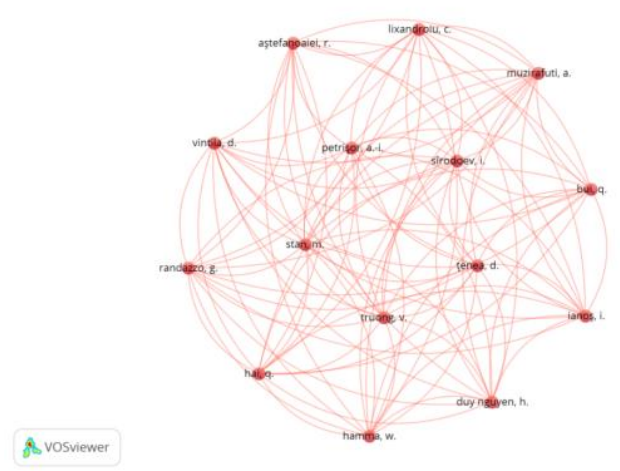

Figure 3. (Mapping data author with Network Visualization model)

Some of the authors listed in the table are authors who conducted previous research related to regional tourism development planning studies. These authors have studied several related articles, for example, Petrişor et al. (2020), who studied "Degradation of coastlines under the pressure of urbanization and tourism: Evidence on the change of land systems from Europe Asia and Africa". In his writings, he found that in tourism development and the need to develop and enforce policies related to tourism, it was necessary to consider ecosystem resilience. Therefore these findings underscored the importance of cooperation in policy development so that undesirable things did not happen.

Otherwise, Ivars-Baidal et al. (2021), in their article entitled "Sustainable tourism indicators: what's new within the smart city/destination approach?" describe the tangible (limited) contribution that smart cities/destinations make to sustainable tourism development and contribute to identifying weaknesses and opportunities to guide smart policies and projects. Understanding to read this opportunity is very influential in efforts to develop tourism in an area. This paper captures and contextualizes the findings within a new framework of smart sustainability and highlights the need to strengthen public governance of urban spaces and tourism. The importance of sustainable tourism is a fundamental factor in the development of regional tourism.

It is undeniable that previous studies examined by several authors are very influential for new writers who study related themes. Previous articles written by some of these authors can also be used as benchmarks and learners in learning regional tourism development in Indonesia in the future. It should understand that it is not easy to study and analyze related to regional tourism development efforts. Underlying this, the author who raised the theme of associated studies must understand previous studies. From these various reasons, it can be understood how valuable previous research is to compile research related to regional tourism development.

The names of other authors who cannot be described one by one also wrote related themes related to regional tourism development. For example, Siridoev, Duy Nguyen, Randazzo, Ianos, and several other authors. Some names of these authors are also quoted or included in the study of tourism development in this area.

Next, the author listed the author's data mapping with the Density Visualization method. Also included is This method for the completeness and breadth of the presentation of the study conducted. The picture is as follows.

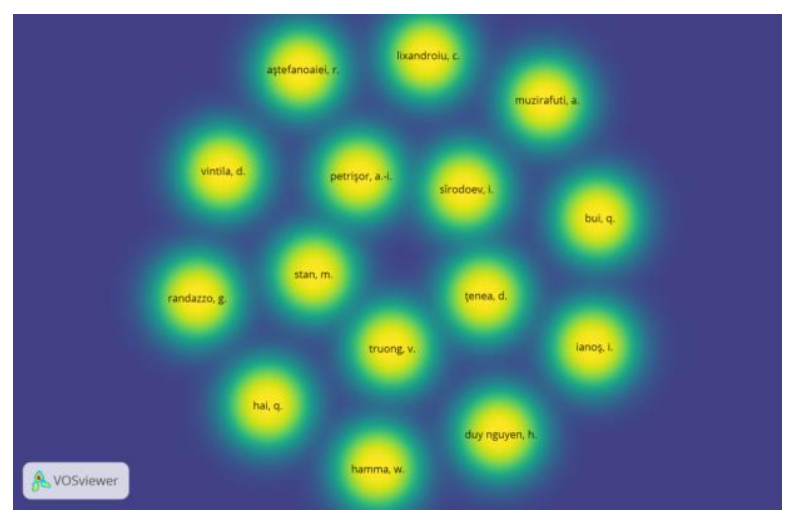

Figure 4. (Mapping author data with Density Visualization method).

Based on data mapping author through the Density Visualization method, it can be understood that there is no fundamental cluster difference for the authors. It means that there is only one 
cluster from the author category about the study of regional tourism development. The author's position can also be seen as quite egalitarian, that no one is too dominant between one another. It indicated that the theme related to the study of regional tourism development did not have articles focused on only one or two authors.

Table 3. (Author grouping in regional tourism development studies)

\begin{tabular}{|c|l|c|}
\hline Cluster & \multicolumn{1}{|c|}{ Author Name } & $\begin{array}{c}\text { Tot } \\
\text { al }\end{array}$ \\
\hline $\begin{array}{c}\text { Cluster } \\
1\end{array}$ & $\begin{array}{l}\text { Truong, V. Stan, m. Petrisor, a.-i. } \\
\text { Sirodoev, i. Tenea, d. Hamma, w. Duy } \\
\text { Nguyen, p. Ianos, i. Bui, q. Muzirafuti, }\end{array}$ & 14 \\
& $\begin{array}{l}\text { a. Lixandroiu, c. Astefanoaiei, r. } \\
\text { Vintila, d. Randazzo, g. and Hi, q. }\end{array}$ & \\
\hline
\end{tabular}

Monolithic with the previous description, in the study conducted by the author using VOSViewer regarding the study of regional tourism development, there was no grouping of authors based on different clusters or could state that they consisted of only one group. It indicated that all the authors listed above wrote articles relevant to regional tourism development studies. It is what causes no vital differences in the grouping of author names based on related themes.

\section{CONCLUSION}

Based on the study conducted by the authors, we can conclude that planning was very important in developing regional tourism. Regional tourism development was a complex problem faced by several countries. Various methods found from previous studies, especially from foreign countries, could be collaborated and used as a reference to deal with the problems of regional tourism development in Indonesia.

Some findings obtained from various previous studies regarding the development of regional tourism in several countries and could be used as a reference for developing regional tourism in Indonesia in the future are as follows: First, there is a well-integrated collaboration. The perfect partnership between the government, residents, business people, and other private parties is a major factor in supporting tourism development in the region. Second, the strong political will from the government, both central and regional/village. Initiated The government's strong desire to develop regional tourism was in the form of regulations and rules in the field. Third, the presence or active participation of the local community. Local communities, in this case, can contribute such as advice to the government regarding regional tourism so that the government can take policies with a bottom-up system pattern. Fourth, carried planning out in a systematic and wellintegrated manner. In this case, the government as the policymaker must make a careful and integrated plan so that it could be in line with the ecological, economic, cultural vision and related regional tourism resources. Finally, the fifth is the subject involved as policymakers. Monolithic with the second point, the issue was the government (central and local). Policymakers were fundamental subjects in regional tourism development, because success in developing large regional tourism depends on the government.

The limitations of this study were the lack of comprehensive comparisons reviewed in each cluster. It was based on the rules of the data found by the authors, especially those that were only contained in the SCOPUS database. With these limitations, it is expected that further research can enrich references from other databases to see the conceptualization of what is being studied based on different approaches. Thus, the discussion of regional tourism development can be a detailed study and very useful in influencing future regional tourism development policies in Indonesia.

\section{BIBLIOGRAPHY}

Almeida, I., \& Silveira, L. (2021). Collaborative Tourism Planning in Small Municipalities. The Creation of a Local Development Strategy for Pombal (Portugal) Through the Application of the Delphi Technique . Revista Portuguesa de Estudos Regionais, 57, 57-69. https://www.scopus.com/inward/record.uri ?eid=2-s2.0-

85101550514\&partnerID $=40 \&$ md5 $=9 a 4 b e 3$ 5c0b6d6750868319be58d04bc3

Anandhyta, A. R., \& Kinseng, R. A. (2020). Hubungan Tingkat Partisipasi dengan Tingkat Kesejahteraan Masyarakat dalam 
Zainul Rahman \& Salahudin, Regional Tourism Development Planning: A Literature Review

Pengembangan Wisata Pesisir. Jurnal Nasional Pariwisata, 12(2), 68. https://doi.org/10.22146/jnp.60398

Brillo, B. B. C. (2020). Initiation and establishment of ecotourism development: Pandin Lake of San Pablo City and Tayak Hill of Rizal, Laguna, Philippines. GeoJournal. https://doi.org/10.1007/s10708-02010216-1

Caamaño-franco, I., \& Suárez, M. A. (2020). The value assessment and planning of industrial mining heritage as a tourism attraction: The case of Las Médulas cultural space. Land, $9(11)$, 1-22. https://doi.org/10.3390/land 9110404

Candia, S., Pirlone, F., \& Spadaro, I. (2020). Integrating the carrying capacity methodology into tourism strategic plans: A sustainable approach to tourism. International Journal of Sustainable Development and Planning, 15(3), 393-401. https://doi.org/10.18280/ijsdp.150317

Casanova Enault, L., Popoff, T., \& Debolini, M. (2021). Vacant lands on French Mediterranean coastlines: Inventory, agricultural opportunities, and future scenarios. Land Use Policy, 100. https://doi.org/10.1016/j.landusepol.2020. 104914

Chen, H.-S. (2020). The construction and validation of a sustainable tourism development evaluation model. International Journal of Environmental Research and Public Health, 17(19), $1-20$. https://doi.org/10.3390/i jerph17197306

de la Calle-Vaquero, M., García-hernández, M., \& de Miguel, S. M. (2021). Urban planning regulations for tourism in the context of overtourism. Applications in historical centers. Sustainability (Switzerland), 13(1), 1-21. https://doi.org/10.3390/su13010070

El Hadj Mimoune, A., Salem, S., \& Kacemi, M. (2020). Tourism development and promotion project of El Mechouar citadel: Issues and limitations. A/Z ITU Journal of the Faculty of Architecture, 17(2), 1-13. https://doi.org/10.5505/itujfa.2020.46362

Eyisi, A., Lee, D., \& Trees, K. (2020). Facilitating collaboration and community participation in tourism development: The case of SouthEastern Nigeria. Tourism and Hospitality Research. https://doi.org/10.1177/146735842096603 5

Hengky, S. H., \& Kikvidze, Z. (2020). Sustainable Coastal Tourism in Tanjung Kelayang, Indonesia. Tourism Planning and Development. https://doi.org/10.1080/21568316.2020.17 63444

Hui, T. S. O. K., Ai Lin, E. L., \& Mamat, M. P. (2020). Local community participation in ecotourism at National Park in Pahang, Malaysia. Malaysian Forester, 83(2), 340-352. https://www.scopus.com/inward/record.uri ?eid=2-s2.0 -

85098329691\&partnerID=40\&md5=b4491d 7e394f7f7e81ac34e677c0e58b

Ignaccolo, M., Inturri, G., Giuffrida, N., \& Torrisi, V. (2020). A sustainable framework for the analysis of port systems. European Transport - Trasporti Europei, 78, 1-19. https://www.scopus.com/inward/record.uri ?eid=2-s2.0 85090098518\&partnerID $=40 \& m d 5=8 a 8239$ c6ea32efc1a30ce4cf3a284f0 6

Ivars-Baidal, J. A., Vera-Rebollo, J. F., Perles-Ribes, J., Femenia-Serra, F., \& Celdrán-Bernabeu, M. A. (2021). Sustainable tourism indicators: what's new within the smart city/destination approach? Journal of Sustainable Tourism. https://doi.org/10.1080/09669582.2021.18 76075

Kalvet, T., Olesk, M., Tiits, M., \& Raun, J. (2020). Innovative tools for tourism and cultural tourism impact assessment. Sustainability (Switzerland), 12(18). https://doi.org/10.3390/SU12187470

Karahan, F., \& Davardoust, S. (2020). Evaluation of vernacular architecture of Uzundere District (architectural typology and physical form of building) about ecologically sustainable development. Journal of Asian Architecture and Building Engineering, 19(5), 490-501. https://doi.org/10.1080/13467581.2020.17 58108

Kyvelou, S. S. I., \& Ierapetritis, D. G. (2020). Fisheries sustainability through soft multiuse maritime spatial planning and local development co-management: Potentials and challenges in Greece. Sustainability (Switzerland), 12(5). https://doi.org/10.3390/su 12052026

Li, W.-B., Zhang, L., \& Guo, R.-L. (2020). The measurement of tourism environmental pollution and tourism efficiency in Western China. Journal of Coastal Research, 104(sp1), 660-664. https://doi.org/10.2112/JCRSI104-114.1

Lopes, V., Pires, S. M., \& Costa, R. (2020). A strategy for sustainable tourism development of the Greek Island of Chios. Tourism, 68(3), 243260. https://doi.org/10.37741/T.68.3.1

Luhtala, H., Erkkilä-Välimäki, A., Eliasen, S. Q., \& Tolvanen, H. (2021). Business sector involvement in maritime spatial planning Experiences from the Baltic Sea region. 
Marine

Policy, https://doi.org/10.1016/j.marpol.2020.104 301

Majerska-Pałubicka, B., \& Latusek, E. (2020). A concept of the development of riverside embankment in the context of Cracow (a local center). Buildings, 10(3). https://doi.org/10.3390/buildings1003005 6

Nel, E., \& Connelly, S. (2020). Regional economic transformation: Changing land and resource access on the West Coast of New Zealand's South Island. Land Use Policy, 93. https://doi.org/10.1016/j.landusepol.2019. 04.008

Nguyen, H. V, Diane, L., \& Newsome, D. (2020). Kinh and ethnic tourism stakeholder participation and collaboration in tourism planning in Sapa, Vietnam. International Journal of Culture, Tourism, and Hospitality Research, 14(4),

579-597.

https://doi.org/10.1108/IJCTHR-12-20180179

Pebriana, F., Mulyawan, R., \& Sutrisno, B. (2021). Strategi pemerintah daerah dalam pengembangan pariwisata untuk meningkatkan pendapatan asli daerah. 1(April), 11-22.

Petrişor, A.-I., Hamma, W., Duy Nguyen, H., Randazzo, G., Muzirafuti, A., Stan, M., Truong, V., Aștefanoaiei, R., Bui, Q., Vintila, D., Hai, Q., Lixandroiu, C., Ţenea, D., Sîrodoev, I., \& Ianoş, I. (2020). Degradation of coastlines under the pressure of urbanization and tourism: Evidence on the change of land systems from Europe, Asia, and Africa. Land, 9(8). https://doi.org/10.3390/LAND9080275

Prathama, A., Nuraini, R. E., \& Firdaus, Y. (2020). Pembangunan Pariwisata Berkelanjutan Dalam Prespektif Lingkungan (Studi Kasus Wisata Alam Waduk Gondang Di Kabupaten Lamongan). Jurnal Sosial, Ekonomi Dan Politik, Volume 1(3), 29-38. http://www.jsep.org/index.php/jsep/article /view/17

Phuc, H. N., \& Nguyen, H. M. (2020). The importance of collaboration and emotional solidarity in residents' support for sustainable urban tourism: case study Ho Chi Minh City. Journal of Sustainable Tourism. https://doi.org/10.1080/09669582.2020.18 31520

Ponte, J. C., Couto, G., Pimentel, P., Sousa, Á., \& Oliveira, A. (2020). Municipal Tourism Planning in an Island Territory: The Case of Ribeira Grande in the Azores. Tourism Planning and Development. https://doi.org/10.1080/21568316.2020.18 16567
Ratnasari, S. L., Susanti, E. N., Ismanto, W., Tanjung, R., Darma, D. C., \& Sutjahjo, G. (2020). An experience of tourism development: How is the strategy? Journal of Environmental Management and Tourism, 11(7), 18771886.

https://doi.org/10.14505/jemt.v11.7(47).26

Saneinia, S., Gholizadeh, A., \& Zhou, R. (2020). A holistic view of tourism development and potential policy concerns: A case of Birjand City, Iran. African Journal of Hospitality, Tourism and Leisure, 9(1), 1-17. https://www.scopus.com/inward/record.uri ?eid=2-s2.085078229790\&partnerID $=40 \&$ md $5=2 c c 85 c$ 9bea6c3c6a5323c6af4efd28ee

Silviana, A., Ardani, M. N., \& Satria, M. N. (2020). Spatial zoning and community partnership on the development of coastal and marine resources in tourism spots of Bali and Lombok. International Journal of Pharmaceutical Research, 13(1), 948-954. https://doi.org/10.31838/ijpr/2021.13.01.1 58

Syapsan, \& Diartho, H. C. (2020). Natural tourism area development (Study on jember district tourism development). International Journal of Scientific and Technology Research, 9(3), 3783-3790.

https://www.scopus.com/inward/record.uri ?eid=2-s2.085082688273\&partnerID=40\&md5=e12a94 5de426c6ad933de91cc3fa 3197

Tanaka, N., Ikaptra, Kusano, S., Yamazaki, M., \& Matsumoto, K. (2021). Disaster tourism as a tool for disaster storytelling. Journal of Disaster Research, 16(2), 157-162. https://doi.org/10.20965/jdr.2021.p0157

Wang, Y. (2020). Institutional interaction and decision making in China's rural development. Journal of Rural Studies, 76, 111-119.

https://doi.org/10.1016/j.jrurstud.2020.04. 023

Wikantiyoso, R., Cahyaningsih, D. S., Sulaksono, A. G., Widayati, S., Poerwoningsih, D., \& Triyosoputri, E. (2021). Development of Sustainable Community-Based Tourism in Kampong Grangsil, Jambangan Village, Dampit District, Malang Regency. International Review for Spatial Planning and Sustainable Development, 9(1), 64-77. https://doi.org/10.14246/IRSPSD.9.1_64

Wondirad, A., Kebete, Y., \& Li, Y. (2021). Culinary tourism as a driver of regional economic development and socio-cultural revitalization: Evidence from Amhara National Regional State, Ethiopia. Journal of Destination Marketing and Management, 19. 
Zainul Rahman \& Salahudin, Regional Tourism Development Planning: A Literature Review

https://doi.org/10.1016/j.jdmm.2020.1004

82. 